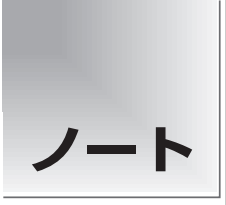

論文受付

2008年9月9日 論文受理 2009年 4 月16日 Code No. 254

\section{FCRを用いたマンモグラフィシステム専用品質管理 ツールとしての 1Shot Phantomの評価}

\author{
長島千恵子 - 内山菜智子 - 森山紀之 - 永田実緒 ${ }^{1)}$ - 小林宏之 ${ }^{2)}$ \\ 三小田勝博 ${ }^{3)}$ ・早乙女滋 ${ }^{4)} \cdot$ 田木正浩 ${ }^{4)}$ ・楠木哲郎 ${ }^{4)}$ \\ 国立がんセンターがん予防・検診研究センター \\ 1 ) 国立がんセンター中央病院放射線診断部 \\ 2) 日本医科大学付属病院放射線科 \\ 3)富士フイルムメディカル株式会社 \\ 4)富士フイルム株式会社
}

\section{緒 言}

近年, 日本人女性の乳癌罹患率および死亡率は増 加している1,2)。早期乳癌を発見するため，2000年よ りマンモグラフィと視触診を併用した乳癌検診が導 入され，マンモグラフィの精度管理の重要性が指摘 されるようになった ${ }^{3)}$. 高品質なマンモグラフィを実 施するため, 装置の定期的, 日常的品質管理は, 非 常に重要である4 6). 通常, マンモグラフィの日常品
質管理における画像評価では, American College of Radiology (ACR) 推奨ファントムを用いた画像の視覚 評価を行っている4 6). しかし，最近ではデジタルマ ンモグラフィの普及に伴い，定量的物理評価による 品質管理が求められるようになってきている。ヨー ロッパのマンモグラフィ検診・診断の品質保証(quality assurance：QA)および品質管理 (quality control : QC)に関する検討組織 European Reference Organiza-

\title{
Evaluation of the 1Shot Phantom Dedicated to the Mammography System Using FCR
}

\author{
Chieko Nagashima, Nachiko Uchiyama, Noriyuki Moriyama, Mio Nagata, ${ }^{1)}$ Hiroyuki Kobayashi, ${ }^{2)}$ \\ Katsuhiro Sankoda, ${ }^{3)}$ Shigeru Saotome, ${ }^{4)}$ Masahiro Tagi, ${ }^{4)}$ and Tetsurou Kusunoki ${ }^{4)}$ \\ Research Center for Cancer Prevention and Screening, National Cancer Center \\ 1 ) Department of Radiology, National Cancer Center Hospital \\ 2) Department of Radiology, Nippon Medical School \\ 3) Fujifilm Medical Corporation \\ 4) Fujifilm Corporation \\ Received September 9, 2008; Revision accepted April 16, 2009 ; Code No. 254
}

\section{Summary}

Currently daily quality control (QC) tests for mammography systems are generally evaluated by using visual analysis phantoms, which of course means subjective measurement. In our study, however, we evaluated a novel digital phantom, the 1Shot Phantom M plus (1Shot Phantom), together with automatic analysis software dedicated for mammography systems using Fuji computed radiography (FCR). The digital phantom enables objective evaluation by providing for actual physical measurement rather than subjective visual assessment. We measured 1) contrast to noise ratio (CNR), 2) image receptor homogeneity, 3) missed tissue at chest wall side, 4) modulation transfer function (MTF), and 5) geometric distortion utilizing the 1Shot Phantom. We then compared the values obtained using the 1Shot Phantom with values obtained from the European guidelines and International Electrotechnical Commission (IEC) standards. In addition, we evaluated the convenience of using the digital phantom. The values utilizing the 1Shot Phantom and those from the European guidelines and IEC standards were consistent, but the QC tests for the European guidelines and IEC standards methods took about six hours while the same QC tests using the 1 Shot Phantom took 10 minutes or less including exposure of the phantom image, measurement, and analysis. In conclusion, the digital phantom and dedicated software proved very useful and produced improved analysis for mammography systems using FCR in clinical daily QC testing because of their objectivity and substantial time-saving convenience.

Key words: mammography, quality control, physical measurement, European guidelines

別刷資料請求先： $\overline{1} 104-0045$ 東京都中央区築地 5-1-1

国立がんセンターがん予防・検診研究センター検診開発研究部＼cjkstart長島千恵子＼cjkstart宛 
tion for Quality Assured Breast Screening and Diagnostic Services (EUREF)は，2006年にデジタルマンモグ ラフイの品質管理に関して，撮影線量と画質に関する 定量的な画質評価法と厳密な規格值を設定したガイ ドライン7)(以下：European guidelines)を発行してい る. 更にInternational Electrotechnical Commission (IEC)も，2007年にデジタルマンモグラフィの受け入 れ検査規格を発行し ${ }^{8)}$, 定量評価による品質管理を推 奨している.

システムの客観的な評価には，このような定量解 析を用いることが望ましいが，作業が繁雑で，解析 にも時間を要するため, 受け入れ試験や定期点検時 に実施することは可能であっても，日常品質管理に取 り入れることは難しいと考えられていた。そこで，1 回のファントム撮影で, 複数項目の画質の定量解析 を実施することができる，1Shot Phantom M plus （富士フイルム社製：以下 1 Shot Phantom)が開発さ れた。今回使用した 1Shot Phantomは, FCR (Fuji Computed Radiography)を用いたマンモグラフィ専用 の品質管理ツールである. 1Shot Phantomでは, 画像 の自動解析と履歴管理を行うQCソフトウェアを使用 して，定量解析による画質評価を簡便かつ短時間で 実施することができる，更に，解析值の変動から，画 質の不変性を確認することで, 装置の性能維持を検 証する不変性試験を実施することが可能なツールで ある。すなわち，1Shot Phantomを使用することによ り，簡便に定量解析による不変性管理を実施するこ とが可能である。現在, 日本ではデジタルマンモグラ フイ装置の品質管理法は明確に定められておらず, 評価項目や管理基準については今後検討する必要性 があるが，このようなツールを日常品質管理の一環と して使用することで，品質管理の客観性，および精 度の向上が期待される。今回われわれは, 1 Shot Phantomの測定精度と測定の簡便性について検討を 行ったので報告する.

\section{1. 方 法}

\section{1-1 使用装置}

すべての測定において，画像読み取り装置はFCR PROFECT CS (富士フイルム社製)を使用した。測定 精度の検討において, 乳房X線撮影装置は, MAMMOMAT3000Nova(SIEMENS社製) および MAMMOMAT3000(SIEMENS社製)の 2 台を使用 し，それぞれの装置を使用した画像取得システム を，システムA，システムBとした。また，MTF測定 については, 測定法間の差異の検討に, 乳房X線撮 影装置Senographe DMR+ (GE社製)を使用した。

\section{1-2 検討項目}

1Shot Phantomの日常品質管理項目のなかから, コ ントラストノイズ比 (contrast to noise ratio : CNR), 画像均一性, 胸壁欠損, 空間分解能 (modulation transfer function : MTF), 画像歪の 5 項目について, European guidelinesに準拠した測定との比較実験を行 い, 測定精度および測定の簡便性の検討を行った。 現在, 日本ではデジタルマンモグラフイ装置における 日常品質管理の方法が, 明確に定められていない. また，日本のガイドラインの指標となっている Mammography Quality Standard Act (MQSA)等の米 国のガイドラインでは，デジタルマンモグラフイ装置 の品質管理は装置ごとに作成されたQCマニュアルに 従うものであり，標準化された共通の規格が存在し ていない. 今回ファントムの精度評価を行うため, マ ンモグラフィの品質管理において，ヨーロッパのガイ ドラインの一つであり, 撮影線量と画質に関する定量 的な画質評価法と厳密な規格值を詳細に設定し, IECの受け入れ試験にも採用されているEuropean guidelinesに準拠した測定法による比較実験を行っ た。なお，European guidelinesに明確な測定方法が記 載されていない項目についてはIECに準拠した測定を 行った。測定項目ごとに撮影を10回繰り返し測定し， 平均值を算出して結果とした。 以下に各項目の評価 法を記す。

\section{1-3 1Shot Phantomによる測定}

1Shot Phantomの構成および評価項目をFig. 1に示す.

戝中aは, CNR測定用の関心領域(region of interest： ROI）設定エリア[向かって右側のエリアにAluminum (Al) objectを配置]，bは画像均一性測定用の 5 力所の ROI設定エリア, cは胸壁欠損測定用チャート, $\mathrm{d}$ は空 間分解能測定用のリファレンス領域を有する矩形波 チャート, eは画像歪測定用のline objectを示す。更 に，fは低コントラスト検出能測定用ディスク，gは線 形性測定用のステップウェッジチャートを示し，hは システム感度不変性測定エリア，iはダイナミックレ ンジ測定エリアで，線形性の測定に用いるステップ ウェッジチャートの最薄部を使用している.

また，1Shot Phantomはベースに厚さ2.26mmのAlを 使用しており，厚さ40mmのpolymethyl methacrylate (PMMA)を $28 \mathrm{kV}, \mathrm{Mo} / \mathrm{Mo}$ で撮影したときと透過線 量が同じになるように設計されている。通常，1Shot Phantomは上記条件下で, automatic exposure control (AEC)モードを使用して撮影するが, 今回は線量の ばらつきによる測定值への影響を避けるため, マニュ アルモードを使用し，撮影条件を一定にして撮影を 行った. 撮影線量については, 厚さ40mmのPMMAを 


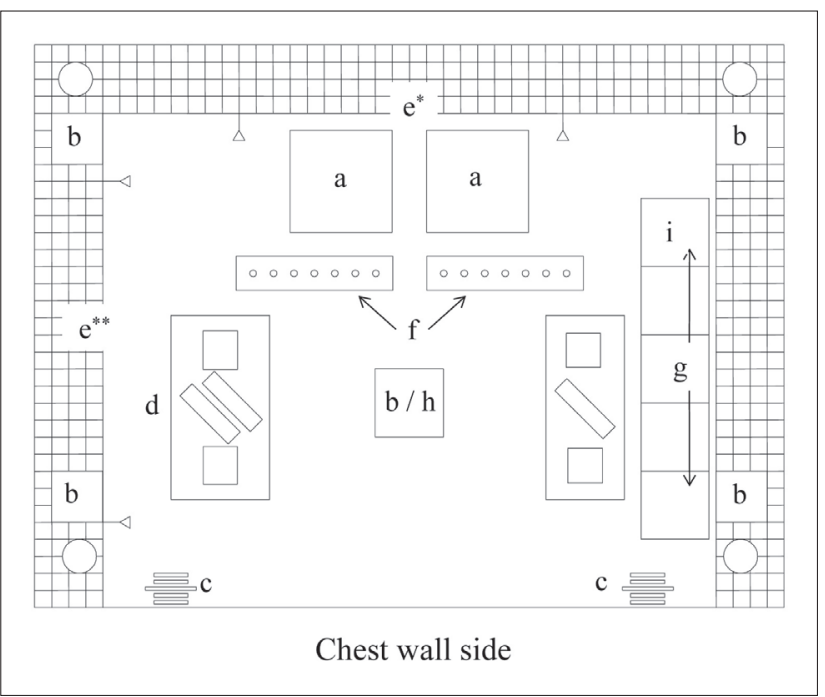

Fig. 1 Evaluation items of the 1Shot Phantom (for daily quality control)

a: CNR, b: Image receptor homogeneity, c: Missed tissue at chest wall side, d: MTF, e: Geometric distortion, f: Low contrast detectability, g: Image receptor response, h: System sensitivity constancy, i: Dynamic Range

*: main scan direction, ${ }^{* *}$ : sub scan direction

Mo/Mo，28kV，AECモードで撮影したとき設定され るmAs值を使用した。また, imaging plate (IP)の フェーディングによる影響を避けるため，X線曝射後 から画像読み取りまでの時間を 1 分間とした。

各項目の評価法の詳細について1Shot Phantomと European guidelinesの定義を交え，以下にまとめる. なお, European guidelinesで使用する標準ファントム は厚さ $45 \mathrm{~mm}$ で検出器全面を覆う大きさのPMMAで あるが，1Shot Phantomと比較を行うため, PMMA ファントム使用時は，厚さ $40 \mathrm{~mm}$ で $18 \times 24 \mathrm{~cm}$ のIPを覆 うことができる大きさのものを使用した。

\section{1-3-1 CNR解析}

1Shot Phantom内部には, 厚さ0.2mmのAl objectが 配置されている. Fig. 2aに示すように， background (BG)部にROI1を，Al objectによる信号部にROI2を， 設定する．各ROIの平均画素值(mean pixel value： $\mathrm{PV}$ ) $\mathrm{m}$, 標準偏差 (standard deviation : SD) $\sigma$ を求め, （1）式により，CNRを算出する。なお，ROIの面積は $4 \mathrm{~cm}^{2}$ で正方形, 胸壁端からの距離は $11.5 \mathrm{~cm}$ である.

$$
\begin{aligned}
& \mathrm{CNR}=\frac{\mathrm{m}_{\mathrm{Al}}-\mathrm{m}_{\mathrm{BG}}}{\sqrt{\frac{\sigma_{\mathrm{BG}}^{2}+\sigma_{\mathrm{Al}}^{2}}{2}}} \ldots \\
& \text { ここで, } \\
& \mathrm{m}_{\mathrm{BG}}: \mathrm{ROI} 1 \text { } \mathrm{PV} \\
& \mathrm{m}_{\mathrm{Al}}: \mathrm{ROI} 2 \text { } \mathrm{PV}
\end{aligned}
$$

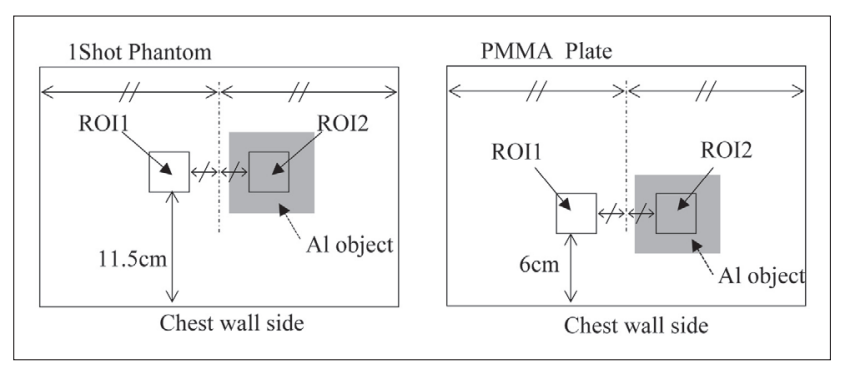

Fig. 2 Position of the Al object and ROI for CNR measurement

(a) Measurement points of the 1 Shot Phantom

(b) Measurement points of the European guidelines

The simple square shows ROI, and the square of the net pattern shows Al object

\section{$\sigma_{\mathrm{BG}}: \mathrm{ROI} 10 \mathrm{SD}$ \\ $\sigma_{\mathrm{Al}}: \mathrm{ROI} 2 \sigma \mathrm{SD}$}

Fig. 2bにEuropean guidelinesの定義によるCNR測 定配置図を示す。A 1 は厚さ0.2mm, PMMAファント ムは検出器全面を覆う大きさのもので厚さ20, 30,

40，45，50，60，70mmに関して評価する。面積 $4 \mathrm{~cm}^{2}$ の正方形のROIを, 胸壁からの距離 $6 \mathrm{~cm}$ の位置 に設定する。今回の比較実験では，厚さ40mmの PMMAファントムと厚さ $0.2 \mathrm{~mm}$ の Al objectを使用し た. ヒール効果の影響を避けるため, 計測するROIの 位置は1Shot Phantomに合わせ，胸壁から $11.5 \mathrm{~cm}$ とし た。撮影条件についても1Shot Phantomと同じとした。

更に, CNR測定值の差異を詳細に解析するため に，(2)式のようにコントラストおよびSN比 (signal to noise ratio：SNR)を定義し，比較を行った。

1Shot Phantomについては，手動でCNR計測位置に ROIを設定し，PVとSDを計測し，コントラスト， SNR, CNRの算出を行った.

$\mathrm{CNR}=\frac{\mathrm{m}_{\mathrm{BG}}-\mathrm{m}_{\mathrm{Al}}}{\sqrt{\frac{\sigma_{\mathrm{BG}}^{2}+\sigma_{\mathrm{Al}}^{2}}{2}}}=\frac{\frac{\mathrm{m}_{\mathrm{BG}}-\mathrm{m}_{\mathrm{Al}}}{\mathrm{m}_{\mathrm{BG}}}}{\sqrt{\frac{\sigma_{\mathrm{BG}}^{2}+\sigma_{\mathrm{Al}}^{2}}{2}} \times \frac{1}{\mathrm{~m}_{\mathrm{BG}}}}=\left(1-\frac{\mathrm{m}_{\mathrm{Al}}}{\mathrm{m}_{\mathrm{BG}}}\right) \times \frac{\mathrm{m}_{\mathrm{BG}}}{\sqrt{\frac{\sigma_{\mathrm{BG}}{ }^{2}+\sigma_{\mathrm{Al}}{ }^{2}}{2}}}$

すなわち，

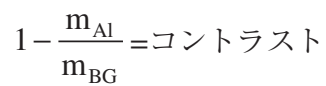

$$
\begin{aligned}
& \frac{\mathrm{m}_{\mathrm{BG}}}{\sqrt{\frac{{\sigma_{\mathrm{BG}}}^{2}+\sigma_{\mathrm{Al}}^{2}}{2}}}=\mathrm{SNR}
\end{aligned}
$$

と定義した。 


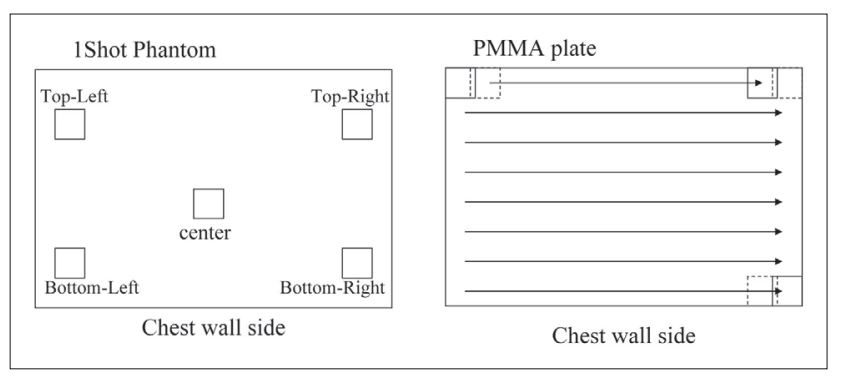

Fig. 3 Position of the ROI for image receptor homogeneity measurement

$a \mid b$

(a) Measurement points of the 1Shot Phantom

(b) Measurement points of the European guidelines

The square shows ROI, the arrow shows scanning direction.

\section{1-3-2 画像均一性}

1Shot PhantomではFig. 3aに示すように画像の四隅 と中央に $1 \mathrm{~cm}^{2}$ のROIを設定し，PVとSNRを測定す る。（3）式拈よび(4)式に従い，画像の四隅それぞれ についてPV比，SNR比を算出する。

$$
\begin{aligned}
& \mathrm{PV} \text { 比 }=\frac{\text { 四隅のROIのPV }}{\text { 中央の } \mathrm{ROI} の \mathrm{PV}} \\
& \mathrm{SNR} \text { 比 }=\frac{\text { 四隅のROIのSNR }}{\text { 中央のROIのSNR }}
\end{aligned}
$$

European guidelinesの定義では，検出器全面を覆 う大きさで, 厚さ $45 \mathrm{~mm}$ のPMMAファントムを臨床撮 影条件で撮影し, Fig. 3bに示すように画像全域を $1 \mathrm{~cm}^{2}$ のROIで走査する。次に, 走査した全ROIのPV とSNRを算出し, 全ROIの平均值と各ROIの測定值の 相対差の最大值をもって評価する，更に，このとき画 像処理は行わないとしている。しかし, 1Shot Phantomが目的とする, 不変性試験においては, 各測定点 でのPV比および，SNR比の経時的変化の確認が行え ればよいと考え, 今回比較実験では, 厚さ40mmの PMMAを撮影し, 1Shot Phantomに準じ, 画像の四隅 と中央にROIを設定し, PV比とSNR比を算出した. 撮影条件についても 1Shot Phantomと同じとした.

\section{1-3-3 胸壁欠損}

1Shot Phantomでは, Fig. 4aに示すような胸壁側の スリット像より胸壁欠損量を算出する。スリット像は 乳房支持台上面から $3 \mathrm{~mm}$ の高さ, 左右 2 力所に配置 されている.（5)式により胸壁欠損Xを算出する.

$$
\mathrm{X}=\mathrm{d}_{2}-\mathrm{d}_{1} / \mathrm{M}
$$

$$
\text { ここで }
$$

$\mathrm{d}_{1}$ : 画像上に描出されたマーカーの長さ

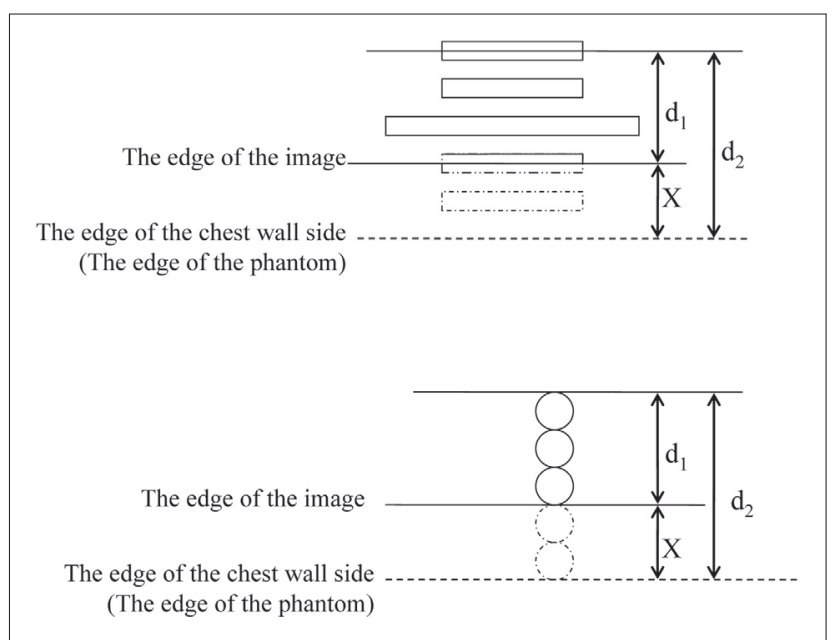

Fig. 4 The markers for the measurement of missed tissue at chest wall side

(a) 1Shot Phantom method

(b) European guidelines method

The squares and circles show slit and iron ball, respectively.

$\mathrm{d}_{1}$ : Length of markers on the image, $\mathrm{d}_{2}$ : Total length of all the markers

$$
\begin{aligned}
& \mathrm{d}_{2} \text { : あらかじめ予測されたマーカーの全長 } \\
& \mathrm{M} \text { : 拡大率 }
\end{aligned}
$$

European guidelinesの定義では, 胸壁端からの距 離計測が可能なマーカーを有するファントムを撮影 し, 画像上でのマーカーの位置より欠損部分の距離 を測定する。今回は, Fig. $4 \mathrm{~b}$ に示すような直径 $2 \mathrm{~mm}$ の鉄球を内蔵した胸壁欠損試験ファントム $(\mathrm{KP} 2 \mathrm{~N}$, 化成オプトニクス社製)を使用した。乳房支持台上面 から $2.5 \mathrm{~mm}$ の高さにある鉄球から得られた鉄球像の 距離を計測し，1Shot Phantomの定義式にならい，左 右の胸壁欠損量を算出した.

また, European guidelinesでは, 画像読み取り時の カセッテ内へのIPの挿入位置の再現性を懸念し，測 定を 5 回以上行jように定めている.IPの挿入位置 の再現性の確認を行うため, 胸壁欠損試験ファント ムを用い，乳房支持台上にファントムを固定したま ま，撮影を 10 回繰り返し，カセッテ内へのIPの挿入位 置の再現性による測定のばらつきを確認した.

\section{1-3-4 空間分解能}

1Shot Phantomでは，IECのマンモグラフィ受け入れ 試験に採用されているstandard deviation法(SD法) ${ }^{9,10)}$ により空間分解能の測定を行っている.SD法では, Fig. 5に示すような, 測定対象の周波数のバーパター ンとX線減衰部，および透過部のリファレンス領域を 有する矩形波チャートを用いる。画像上で, それぞ れの領域に設定したROIの平均画素值m, 標準偏差 $\sigma$ を求め, (6) 式より空間分解能M (f) 算出する. 


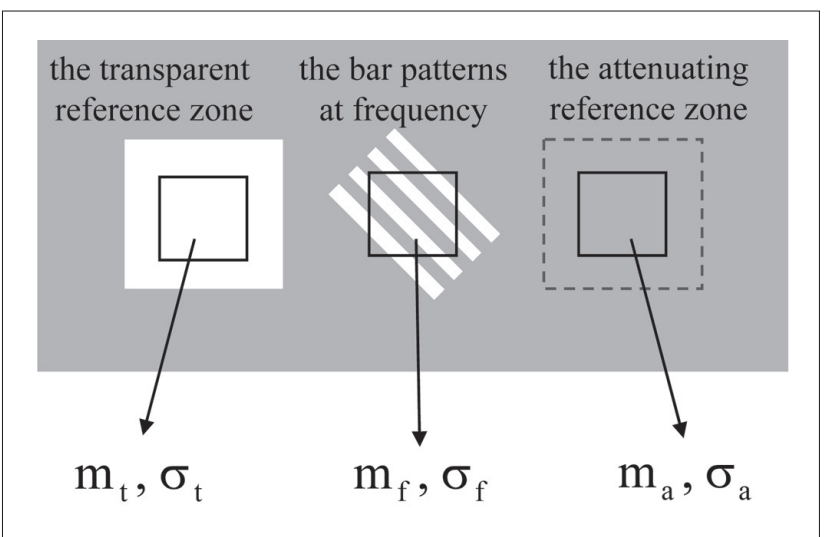

Fig. 5 Standard deviation method

Square shows ROI. "m" is mean pixel value, and " $\sigma$ " is standard deviation.

$$
\begin{aligned}
& \mathrm{M}_{0}=\frac{\sqrt{2}}{\pi}\left|\mathrm{m}_{\mathrm{a}}-\mathrm{m}_{\mathrm{t}}\right| \\
& \sigma^{2}=\frac{\sigma_{\mathrm{a}}^{2}+\sigma_{\mathrm{t}}^{2}}{2} \\
& \mathrm{M}(\mathrm{f})=\frac{\sqrt{\sigma_{\mathrm{f}}^{2}}-\sigma^{2}}{\mathrm{M}_{0}}
\end{aligned}
$$

ここで,

$\mathrm{m}_{\mathrm{a}}: \mathrm{X}$ 線減衰部ROIの平均画素值

$\mathrm{m}_{\mathrm{t}}: \mathrm{X}$ 線透過部ROIの平均画素值

$\sigma_{\mathrm{a}}: \mathrm{X}$ 線減衰部ROIの標準偏差

$\sigma_{\mathrm{t}}: \mathrm{X}$ 線透過部ROIの標準偏差

$\sigma_{\mathrm{f}}:$ バーパターン部ROIの標準偏差

1Shot Phantomでは21p/mmおよび41p/mmのチャー 卜像の評価を行う.

European guidelinesでは, 明確な評価方法を定め ていないため, 今回実験では, IECのdetective quantum efficiency (DQE) 測定法に採択されているエッジ 法 ${ }^{11,12)}$ に準じた測定を行った。解析に用いる画像の取 得は, Fig. 6に示すように厚さ40mmのPMMA上に厚 さ0.8mmのステンレススチール製のエッジファントム を乗せ，エッジ部をX線管球長軸に対し約2.5度傾け て撮影した。取得画像から，エッジ法の手順に従い MTFの算出を行った.

更に，今回それぞれの測定において材質と厚さの 違った散乱体を使用したため，それぞれの散乱体が 測定值に与える影響の程度を検討した。まず，1Shot Phantom撮影時における散乱体の影響を推測するた め, 今回実験手順に従い, 通常通り1Shot Phantomを 撮影した場合と, カセッテ上にファントム内に組み込 まれている矩形波チャートのみを取り出して密着さ せ，散乱体の影響をなくして撮影した場合のMTFを

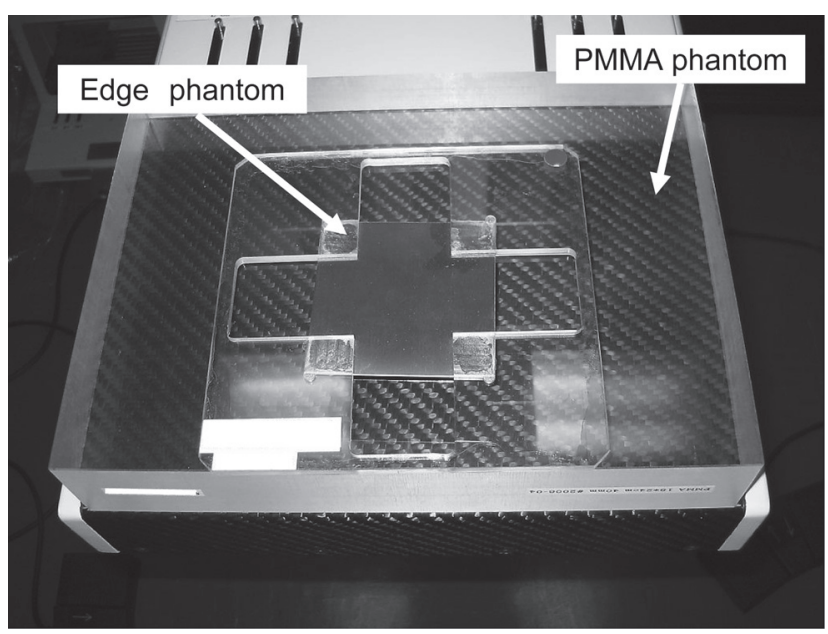

Fig. 6 MTF measurement by the edge method

算出した(Fig. 7a)。エッジ法についても同様に，厚さ 40mmのPMMA上にエッジファントムを乗せて撮影し た場合と，カセッテ上にエッジファントムを密着さ せ，散乱体の影響をなくした状態で撮影した場合 の，MTFを算出した(Fig. 7b).

\section{1-3-5 画像歪}

1Shot Phantomでは，ファントム上で100mmとなる ライン間距離を, 画像上で主走査方向, 副走査方向 のそれぞれについて計測し，この計測した距離を寸 法精度と定義する。

European guidelinesでの定義では, ラインパターン および，メッシュパターンを有するファントムを撮影 する。取得画像上で直線部の距離を計測し，アーチ ファクトまたは目視上の歪みがないことを確認する. また，このとき画像処理を行わないとしている。今回 の比較実験では, メッシュ構造を有するGrid test board (TL0109, TREX Medical Corp.製)を撮影し, ファントム上で $100 \mathrm{~mm}$ のライン間距離を，画像上で主 走査方向，副走査方向のそれぞれについて計測し た。計測の位置は，1Shot Phantomに準じた。更に， 測定值の差異について検証を行うため，各ファントム 使用時の拡大率を算出した.

\section{1-3-6 測定時間}

測定の簡便性を評価するため, 今回各測定に要し た時間を概算した。

\section{2. 結 果}

\section{2-1 CNR}

Table 1にCNRおよび，コントラストとSNRの測定 結果を示す. 1Shot PhantomとEuropean guidelinesに 準拠した方法のCNR測定差はシステムAでは 3.1\%，システムBでは $0.8 \%$ であった。また, 1 Shot 


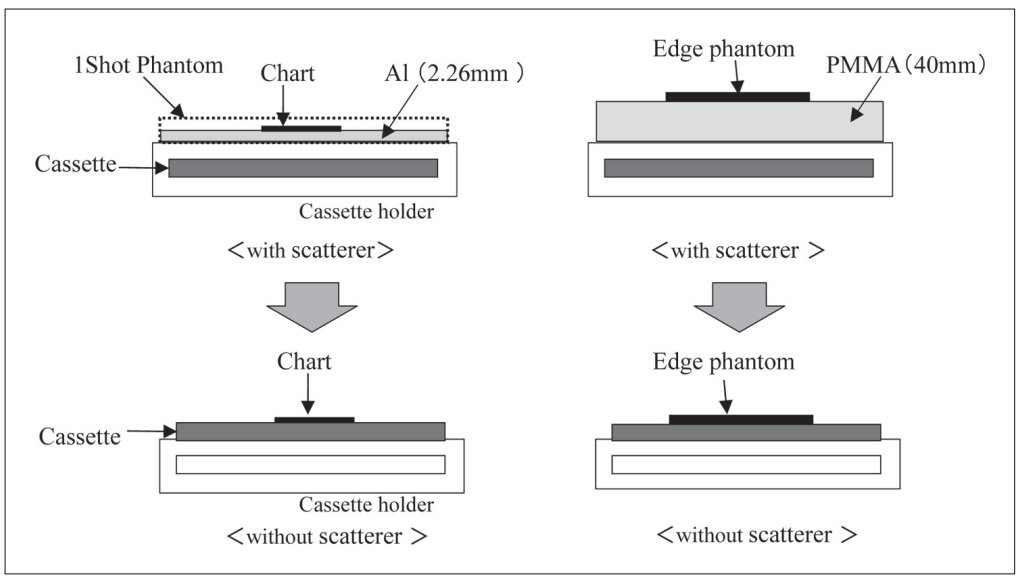

$a \mid b$

Fig. 7 Position of MTF test tool for measurement of influence of scatterer in MTF measurement (a) Measurement of influence from scatterer when measured by 1 Shot Phantom

(b) Measurement of influence from scatterer when measured by edge method

Table 1 Results of CNR measurements

\begin{tabular}{cccccc}
\hline \hline \multicolumn{2}{c}{ Image acquisition system } & 1Shot Phantom & PMMA & 1Shot/PMMA & Significant difference \\
\hline \multirow{3}{*}{ System A } & CNR & 9.58 (manual: 9.50$)$ & 9.29 & $103.1 \%(102.3 \%)$ & $P<0.05(\mathrm{P}<0.05)$ \\
& Contrast & 0.173 & 0.179 & $96.5 \%$ & $\mathrm{P}<0.05$ \\
& SNR & 54.9 & 51.9 & $105.9 \%$ & $\mathrm{P}<0.05$ \\
\hline \multirow{3}{*}{ System B } & CNR & 8.66 (manual: 8.57$)$ & 8.59 & $100.8 \%(99.8 \%)$ & $\mathrm{P}<0.05(\mathrm{P}=0.11)$ \\
& Contrast & 0.176 & 0.175 & $100.3 \%$ & $\mathrm{P}=0.46$ \\
& SNR & 46.5 & 46.3 & $100.4 \%$ & $\mathrm{P}<0.05$ \\
\hline
\end{tabular}

The value in the parentheses of CNR data expresses a manually operated calculated value.

Table 2 Results of image receptor homogeneity measurements

\begin{tabular}{|c|c|c|c|c|c|c|c|c|c|}
\hline \multirow{2}{*}{\multicolumn{2}{|c|}{ Image acquisition system }} & \multicolumn{4}{|c|}{ PV ratio [\%] } & \multicolumn{4}{|c|}{ SNR ratio [\%] } \\
\hline & & $\begin{array}{c}\text { 1Shot } \\
\text { Phantom }\end{array}$ & PMMA & Difference & $\begin{array}{l}\text { Significant } \\
\text { difference }\end{array}$ & $\begin{array}{c}\text { 1Shot } \\
\text { Phantom }\end{array}$ & PMMA & Difference & $\begin{array}{l}\text { Significant } \\
\text { difference }\end{array}$ \\
\hline \multirow{4}{*}{ System A } & Top-Right & -22.5 & -27.4 & 4.9 & $\mathrm{P}<0.05$ & -12 & -14.6 & 2.6 & $\mathrm{P}<0.05$ \\
\hline & Top-Left & -22.5 & -26 & 3.5 & $\mathrm{P}<0.05$ & -15.9 & -17.4 & 1.5 & $\mathrm{P}<0.05$ \\
\hline & Bottom-Right & -12 & -13.7 & 1.7 & $\mathrm{P}<0.05$ & -6.2 & -6.9 & 0.7 & $\mathrm{P}<0.05$ \\
\hline & Bottom-Left & -9.7 & -10.4 & 0.7 & $\mathrm{P}<0.05$ & -9.9 & -9.8 & 0.1 & $\mathrm{P}<0.05$ \\
\hline \multirow{4}{*}{ System B } & Top-Right & -27.3 & -28.1 & 0.8 & $P=0.10$ & -15.8 & -16.1 & 0.3 & $P=0.27$ \\
\hline & Top-Left & -27.6 & -33 & 5.4 & $P=0.47$ & -20.6 & -23.5 & 2.9 & $\mathrm{P}<0.05$ \\
\hline & Bottom-Right & -9.4 & -8.3 & 1.1 & $\mathrm{P}<0.05$ & -6 & -4.9 & 1.1 & $P<0.05$ \\
\hline & Bottom-Left & -10.9 & -15.8 & 4.9 & $P<0.05$ & -12.5 & -14.6 & 2.1 & $P<0.05$ \\
\hline
\end{tabular}

Phantomでの計測を，ROIを手動で設定したときの場 合で比較すると，測定差は $2.3 \%$ と $0.2 \%$ となった。こ のときシステムBでは有意差はみられなかった。

各測定におけるコントラストとSNRの比較におい て，システムAでは, 1Shot Phantomの方がコントラス トは3.5\%低く，SNRは5.9\%高かった。 システムBでは 1Shot Phantomの方が，コントラストが $0.3 \%$, SNRが 0.4\%高かったが，コントラスト值には，有意差はみら れなかった。
2-2 画像均一性

Table 2に測定結果を, Fig. 8およびFig. 9に測定位 置による測定值の変動の比較を示す，各測定值の差 はPV比で最大 $5.4 \%$, SNR比で最大 $2.9 \%$ であったが, Fig. 8，Fig. 9に示すように，両測定方法間で，測定位 置による測定值の変動の傾向には類似性がみられた.

\section{2-3 胸壁欠損}

Table 3に測定結果を示す。1Shot Phantomと胸壁欠 


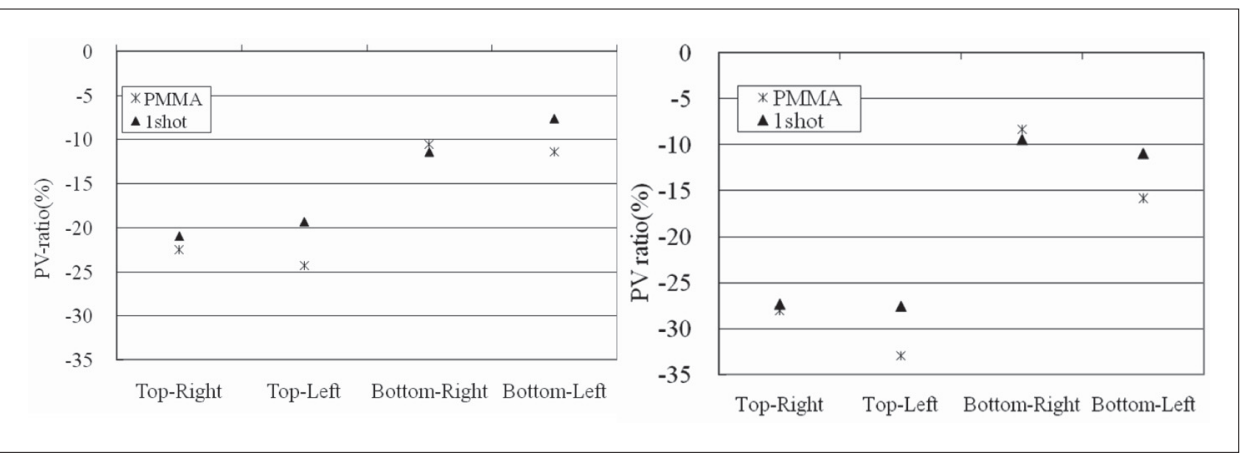

$\mathrm{a} \mid \mathrm{b}$

Fig. 8 Comparison of pixel value ratios in each measurement point

(a) System A

(b) System B

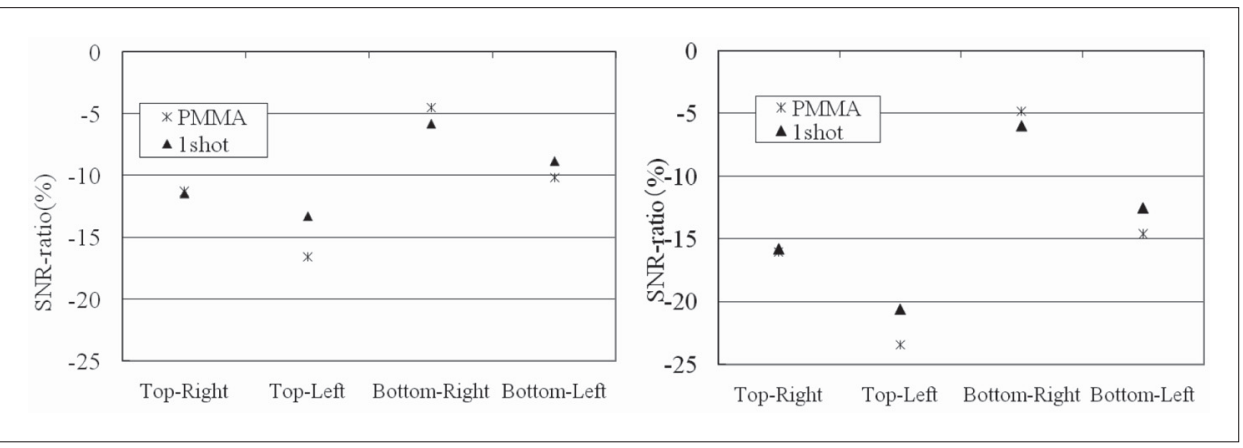

$\mathrm{a} \mid \mathrm{b}$

Fig. 9 Comparison of signal to noise ratios in each measurement point

(a) System A

(b) System B

Table 3 Results of missed tissue at chest wall side measurements

\begin{tabular}{cccccc}
\hline \hline \multicolumn{2}{c}{ Image acquisition system } & $\begin{array}{c}\text { 1Shot Phantom } \\
{[\mathrm{mm}]}\end{array}$ & $\begin{array}{c}\text { Missed tissue } \\
\text { phantom [mm] }\end{array}$ & $\begin{array}{c}\text { Difference } \\
{[\mathrm{mm}]}\end{array}$ & $\begin{array}{c}\text { Significant } \\
\text { difference }\end{array}$ \\
\hline \multirow{2}{*}{ System A } & Right & 4 & 4.2 & 0.2 & $\mathrm{P}<0.05$ \\
& Left & 4 & 4.2 & 0.2 & $\mathrm{P}<0.05$ \\
\hline \multirow{2}{*}{ System B } & Right & 3.4 & 3.6 & 0.2 & $\mathrm{P}<0.05$ \\
& Left & 3.6 & 3.8 & 0.2 & $\mathrm{P}<0.05$ \\
\hline
\end{tabular}

損試験ファントム測定值の差は， $0.2 \mathrm{~mm}$ であった。

また，IPの挿入状態の再現性の試験では，10回の 測定において平均值に対する変動 (変動係数：coefficient of variation：CV)は, 2.2\%であり,このとき, 最大值4.37, 最小值4.10, 最大偏差は0.14mmであっ た。

\section{2-4 空間分解能}

Table 4に測定結果を示す. 1Shot Phantomでは, エッジ法に比べ約 $20 \%$ 高い值を示した。 また, 両測 定法において，散乱体の影響をなくした場合の測定 值の結果をTable 5に示す。散乱体ありでは, $21 \mathrm{p} / \mathrm{mm}$ で14.4\%, 41p/mmで16.9\%の差を生じたが, 散乱体な しではそれぞれ0.5\%, $0.9 \%$ 差であった。

\section{2-5 画像歪}

Table 6に測定結果を示す. 1Shot Phantomの測定值
は,メッシュファントムを使用した測定より， 0.4\%か ら0.7\%大きかった。ファントムの拡大率は1Shot Phantomがメッシュファントムに比べ $0.5 \%$ 大きかった.

\section{2-6 測定時間}

European guidelinesに準拠した測定法について， 今回のわれわれの経験では合計 6 時間程度の時間と 繁雑な作業を要したが，1Shot Phantomにおいては10 分以下の時間で簡便に測定を行うことができた.

\section{3. 考 察}

今回の実験にて，1Shot Phantomの測定精度および 使用に対しての簡便性を評価することができた。

CNR測定において，生じた測定差について，検証 を行った. 1Shot Phantom画像の解析值については, 手動でROI計測を行った場合は，自動解析ソフトを使 用した場合に比べ，測定值の差が少ないことより，わ 
Table 4 Results of MTF measurements

\begin{tabular}{cccccc}
\hline \hline Image acquisition system & $\begin{array}{c}\text { 1Shot } \\
\text { Phantom }\end{array}$ & Edge method & 1Shot/Edge & $\begin{array}{c}\text { Significant } \\
\text { difference }\end{array}$ \\
\hline \multirow{2}{*}{ System A } & 2 Ip/mm & 54.2 & 46.1 & $117.6 \%$ & $\mathrm{P}<0.05$ \\
& $4 \mathrm{lp} / \mathrm{mm}$ & 21.6 & 18 & $120.0 \%$ & $\mathrm{P}<0.05$ \\
\hline \multirow{2}{*}{ System B } & $2 \mathrm{lp} / \mathrm{mm}$ & 54.3 & 45.5 & $119.3 \%$ & $\mathrm{P}<0.05$ \\
& $4 \mathrm{lp} / \mathrm{mm}$ & 21.4 & 17.7 & $120.9 \%$ & $\mathrm{P}<0.05$ \\
\hline
\end{tabular}

Table 5 Influence of scatterer in the MTF measurement difference

\begin{tabular}{|c|c|c|c|c|c|c|c|}
\hline & & \multicolumn{2}{|c|}{ 1Shot Phantom } & \multicolumn{2}{|c|}{ Edge method } & \multicolumn{2}{|c|}{ 1Shot/Edge } \\
\hline & & $2 \mathrm{lp} / \mathrm{mm}$ & $4 \mathrm{lp} / \mathrm{mm}$ & $2 \mathrm{lp} / \mathrm{mm}$ & $4 \mathrm{lp} / \mathrm{mm}$ & $2 \mathrm{lp} / \mathrm{mm}$ & $4 \mathrm{lp} / \mathrm{mm}$ \\
\hline \multirow{2}{*}{ MTF } & without scatterer & 55.6 & 22.5 & 55.3 & 22.3 & $100.5 \%$ & $100.9 \%$ \\
\hline & with scatterer & 54.1 & 21.4 & 47.3 & 18.3 & $114.4 \%$ & $116.9 \%$ \\
\hline & Total & $97.4 \%$ & $95.2 \%$ & $86.0 \%$ & $82.0 \%$ & $113.3 \%$ & $116.1 \%$ \\
\hline \multicolumn{2}{|r|}{ Geometric blur } & $98.2 \%$ & $98.0 \%$ & $97.6 \%$ & $95.6 \%$ & $100.6 \%$ & $102.5 \%$ \\
\hline \multicolumn{2}{|r|}{ Magnification } & $102.6 \%$ & $106.7 \%$ & - & - & $102.6 \%$ & $106.7 \%$ \\
\hline \multicolumn{2}{|r|}{ Scatter radiation } & $96.6 \%$ & $91.1 \%$ & $87.7 \%$ & $85.7 \%$ & $110.1 \%$ & $106.3 \%$ \\
\hline
\end{tabular}

Table 6 Results of geometric distortion measurements

\begin{tabular}{cccccccccc}
\hline \hline $\begin{array}{c}\text { Image acquisition } \\
\text { system }\end{array}$ & \multicolumn{2}{c}{$\begin{array}{c}\text { 1Shot Phantom } \\
\text { Main scan } \\
\text { direction }\end{array}$} & $\begin{array}{c}\text { Sub scan } \\
\text { direction }\end{array}$ & $\begin{array}{c}\text { Main scan } \\
\text { direction }\end{array}$ & $\begin{array}{c}\text { Sub scan } \\
\text { direction }\end{array}$ & $\begin{array}{c}\text { Main scan } \\
\text { direction }\end{array}$ & $\begin{array}{c}\text { Sub scan } \\
\text { direction }\end{array}$ & $\begin{array}{c}\text { Main scan } \\
\text { direction }\end{array}$ & $\begin{array}{c}\text { Sub scan } \\
\text { direction }\end{array}$ \\
\hline System A $[\mathrm{mm}]$ & 102.9 & 103.2 & 102.5 & 102.5 & $100.4 \%$ & $100.7 \%$ & $\mathrm{P}<0.05$ & $\mathrm{P}<0.05$ \\
\hline System B $[\mathrm{mm}]$ & 103.0 & 103.1 & 102.5 & 102.7 & $100.5 \%$ & $100.4 \%$ & $\mathrm{P}<0.05$ & $\mathrm{P}<0.05$ \\
\hline
\end{tabular}

ずかにROIの計測位置にずれが生じたことが，測定 差の一因となっていることが考えられる，更に，手動 計測においてもCNRの值に有意な差を生じた，シス テムAについて，コントラストとSNRの成分から，検 証を行った結果，PMMAに比べ1Shot Phantomは, コ ントラストが低く，SNRが高かった。1Shot Phantom のベース材料はA1であり, 厚さ40mmのPMMAと線量 透過率は等しいが，両者においてファントム透過後 の線質に違いが生じたためと考えられる. 1Shot Phantomの方が高エネルギー側の吸収が小さく，ファ ントム透過後のX線の高エネルギー側の成分が多くな り，コントラストがPMMAに比べて低下したものと考 えられる。一方, 透過後X線の高エネルギ一側の成分 が多い分, IPでのX線吸収量が相対的に大きくなり, SNRの向上につながったものと考えられる。今後, 定 量的な分析のためにはX線スペクトル解析が必要で あると考える。しかし，これにより，1Shot Phantomの 目的とする不変性試験に影響を与えるものではない. 画像均一性の測定については, 両測定方法間で,
測定位置による測定值の変動の傾向は類似してお り, 更に, 1Shot Phantomの方が測定位置間のPV比, SNR比の差が小さいことより，PMMAを使用した測 定よりもファントムの厚みの不均一性による影響を受 けにくいと考えられる。よって, 1Shot Phantomは画 像均一性の不変性管理ツールとして十分な測定精度 を有していると考えられる。

胸壁欠損測定においては $0.2 \mathrm{~mm}$ の測定差がみられ た. 測定差の原因としては, カセッテ内へのIPの挿入 状態, ファントムの設置状態, 指標となるマーカーの 位置の精度などが考えられる。定期管理において, 鉄球ファントムなどの測定值を把握したうえで不変性 の確認に使用するには問題はないと考える。また，IP の挿入状態の再現性試験より10回の測定において最 大偏差は $0.14 \mathrm{~mm}$, 最大值と最小值の差は $0.27 \mathrm{~mm}$ み られ，必要に応じ測定を繰り返すことが望ましいと考 えられる。

空間分解能の測定について, 約 $20 \%$ 測定差がみ られたが, MTF測定ツールである, 矩形波チャート 
および，エッジファントムをカセッテに密着させ，撮 影を行った場合，測定差は $1 \%$ 未満に減少した。これ より，今回比較実験でみられた測定差は，被写体の 材質および厚さの違いによる影響から生じたものと考 えられる。その要因としては，1)1Shot Phantomで使 用している矩形波チャート像が, 受像面上では実寸 よりわずかに拡大されて投影されるために起こる周波 数シフトの影響，2) ファントムの厚さの違いによる半 影の影響，3）散乱線の違いによる影響，が考えられ る。しかし，己れらの要因は，線質や焦点被写体間 距離などの測定系に依存し, 影響の程度は撮影装置 ごとに異なるが, 1Shot Phantomの目的とする不変性 試験を行うにあたって問題はないと考えられる。

画像歪の測定については，測定差はファントムの 拡大率の影響によるもので, 1Shot Phantomとメッ シュファントムは同等の測定精度を有していると考え られる。

1Shot Phantomの測定精度について, CNR, 画像均 一性, 胸壁欠損, 空間分解能, 画像歪の 5 項目につ いて, European guidelinesに準拠した方法と測定值を 比較し, 検討を行った。測定值は一致しなかった が, それらの原因解析を行った結果, 不変性試験に おいては問題となる影響はない。 また, 1Shot Phantomは従来の測定法に比べ，測定の簡便性に優れて おり，測定時間を大幅に短縮することが可能であるた め, 日常管理の範囲内での使用も十分に可能である と考えられる。

更に，定期的精度管理により，装置の性能をしっ
かり把握することは重要である。1Shot Phantomを使 用することで，日常管理において，客観性の高い性 能維持の確認が可能となれば，更に，有用性が高ま る.1Shot Phantomは不変性試験により, 装置の性能 の維持を確認するためのツールである，不変性管理 ツールとしての使用の是非を検討するため, 測定精 度の評価を行った。これらより，1Shot Phantomは， 簡便性に優れ，品質管理ツールとして，十分な性能 を有していることが判明した。

今後は, 今回検証した 5 項目以外の測定項目につ いても同様に検証を行うことが必要である.

\section{4. 結 語}

本研究において, 1Shot Phantomの測定精度，簡便 性が証明された。1Shot Phantomにより，FCRを用い たマンモグラフィシステムの日常管理において，客観 性の高い評価を行うことが可能となることが示唆さ れ，本ツールは非常に有用性の高いツールである。

\section{謝 辞}

本研究にご協力いただきました，国立がんセン タ一中央病院放射線診断部診療放射線技師諸氏に 深く感謝いたします。

本研究の一部は第三次対がん10力年戦略総合研究 事業の森山班より援助を受けた。

なお，本論文の要旨は日本放射線技術学会第63回 総会学術大会(2007年 4 月，横浜)において発表した。

\section{参考文献}

1) Matsuda T, Marugame T, Kamo K, et al. Cancer incidence and incidence rates in Japan in 2002: based on data from 11 population-based cancer registries. Japanese Journal of Clinical Oncology 2008; 38(9) : 641-648.

2) 厚生労働省大臣官房統計情報部編. 人口動態統計 1958-2006.

3）厚生労働省老健局老人保健課. 老健第65号.「がん予防 重点健康教育及びがん検診実施のための指針」の一部改 正について. 2000.

4) (社) 日本医学放射線学会, (社) 日本放射線技術学会, マ ンモグラフィガイドライン委員会, 他. 第10章 精度保 証. マンモグラフイガイドライン第 2 版〈増補版〉. 医学書 院, 東京, 2007 ：67-71.

5) 大内憲明 編集. 6 撮影に関する品質管理の実際. マンモ グラフィによる乳がん検診の手引きー精度管理マニュアル 一第 3 版。 日本医事新報社，東京，2004：39-54.

6) 日本放射線技術学会放射線撮影分科会, 乳房撮影ガイド ライン普及班. 放射線医療技術学叢書 第III章 3 品質管 理. 乳房撮影精度管理マニュアル(改訂版). 日本放射線 技術学会，京都，1999：43-99.
7) Perry N, Broeders M, Wolf C de, et al. Digital mammography. European guidelines for quality assurance in breast cancer screening and diagnosis. Fourth edition. European Communities, Luxembourg, 2006: 105-165.

8) IEC61223-3-2 Evaluation and routine testing in medical imaging departments - Part 3-2 : Acceptance tests - Imaging performance of mammographic X-ray equipment safety ed.2.0. 2007.

9) Droege RT, Rzeszotarski MS. Modulation transfer function from the variance of cyclic bar images. Opt Eng 1984; $23(1): 68-72$.

10) Droege RT, Morin RL. A practical method to measure the MTF of CT scanners. Med Phys 1982; 9(5) : 758-760.

11) IEC62220-1-2. Medical electrical equipment-Characteristics of digital X-ray imaging devices-Part 1-2: Determination of the detective quantum efficiency-Detectors used in mammography. 2007.

12) Samei E, Flynn MJ, Reimann DA. A method for measuring the presampled MTF of digital radiographic systems using an edge test device. Med Phys 1998; 25(1): 102-113. 


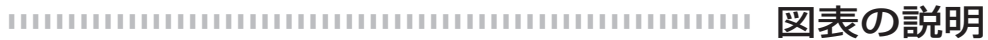

Fig. 1 1Shot Phantomの測定項目（日常品質管理項目）

$\mathrm{a}$ : CNR, b : 画像均一性, $\mathrm{c}$ ：胸壁欠損, $\mathrm{d}$ ：空間分解能, $\mathrm{e}$ ：画像歪, $\mathrm{f}$ : 低コントラスト検出能, $\mathrm{g}:$ 線形性, $\mathrm{h}$ : システ ム感度不変性, i : ダイナミックレンジ

*: 主走查方向, **: 副走查方向

Fig. 2 CNR測定におけるAl objectとROIの配置

(a) 1Shot Phantomの測定位置

(b) European guidelinesの測定位置

白い四角がROIを表し，網掛けの四角がAl objectを表す．

Fig. 3 画像均一性測定位置におけるROIの位置
(a) 1Shot Phantomの測定位置
(b) European guidelines $の$ 測定位置
四角はROIを表し，矢印は走査方向を示す，

Fig. 4 胸壁欠損測定用マーカー
(a) 1Shot Phantom測定法
(b) European guidelines測定法
四角はスリット像，丸は鉄球像を表す。
$\mathrm{d}_{1}$ : 画像上に描出されたマーカーの長さ, $\mathrm{d}_{2}$ ：あらかじめ予測されたマーカーの全長

Fig. 5 SD法

四角はROIを表す. mは平均画素値, $\sigma$ は標準偏差を示す.

Fig. 6 エッジ法によるMTF測定

Fig. 7 MTF測定における散乱体の影響測定時のMTFテストッールの配置
(a)1Shot Phantom撮影時の散乱体からの影響の測定

(b)エッジ法撮影時の散乱体からの影響の測定

Fig. 8 各測定ポイントにおけるPV比の比較
(a)システムA
(b)システム $\mathrm{B}$

Fig. 9 各測定ポイントにおけるSNR比の比較
(a)システム $\mathrm{A}$
(b)システム $B$

Table 1 CNR測定結果

1Shot PhantomのCNR測定值カッコ内の数值は，手動でROI計測を行った際のCNR算出值である.

Table 2 画像均一性測定結果

Table 3 胸壁欠損測定結果

Table 4 MTF測定結果

Table 5 MTF測定における散乱体の影響

Table 6 画像歪測定結果 